\title{
Effects of Fish Farming Land use on Some Soil Chemical Properties and Availability of Some Micronutrients Awad, M.Y. ${ }^{1}$; M.S. Abowaly ${ }^{2}$ and A.S. El-Shahaway ${ }^{3}$ \\ ${ }^{1}$ Dept. of soil Sci., Fac. of Agric., Azhar Univ. Assiut, Egypt \\ ${ }^{2}$ Dept. of soil Sci., Fac. of Agric., Kafr El-sheikh Univ., Egypt \\ ${ }^{3}$ Soil and Water Res., Inst. Giza, Egypt.
}

\section{Abstract:}

Nile river Delta contains the major agricultural and aquacultural base lands in Egypt. Fish farming lands are spread in the northern part of the Nile Delta. Soil/sediments in fish ponds of the Delta are drained and disposed for improving the conditions of bottoms. Land uses include upland cultivation, and short- and long-term of catfish production. It was worthy to examine the influence of fish land use on some soil properties and the availability of some soil micronutrients. Ten soil profiles were chosen to represent the most popular uses of soils in the northern Nile part of the Delta including fish farming. A virgin soil was used as a reference for making comparison among the different practices. The available content of soil $\mathrm{Fe}, \mathrm{Mn}$ and $\mathrm{Cu}$ and their relation with soil properties were studied. The results showed that the available $\mathrm{Mn}, \mathrm{Fe}, \mathrm{Cu}$, and $\mathrm{Zn}$ in the catfish pond soils were higher than north upland cultivated and virgin soils. Available Fe, Mn, Cu and $\mathrm{Zn}$ decreased with increasing the duration use of catfish pond soils and cultivated soils, while available $\mathrm{Zn}$ increased with increasing duration of cultivated soil. Available $\mathrm{Fe}, \mathrm{Mn}, \mathrm{Cu}$ and $\mathrm{Zn}$ showed significant correlations with soil properties. The results may be applicable to other river delta areas of the world.

Keywords: Micronutrients; Fish ponds; Nile Delta soils.

Received on: $16 / 3 / 2014$

Referees: Prof. Mohamed K. Rushdie
Accepted for publication on: 5/4/2014

Prof. Ahmed G. Mohamed 


\section{Introduction:}

To increase animal protein products in Egypt, many fish farms are being recently built. Fish farming has become one of the national targets aimed to reserve amounts of animal protein to fill the diet gap, create new work opportunities, invert soils having bad properties into projects that serve the food security program and finally get better utilization of drainage water. It is well known that the gain expected from using lands in fish farming is higher than that from their use in the conventional agricultural purposes. So, many farmers in the north Delta converted their land activities to fish farming, resulting in a deterioration in the highly productive soils. Fisheries can be established in low quality soils to maintain the productive soils for the better generations. On the other hand, in the case of scarcity of irrigation water, it is worthy to direct waters towards the conventional agricultural purposes. Also, fish can be grown in the different water canals, lakes and seas that are wide spread in Egypt. The solubility and the availability of most soil micronutrients increase with decreasing in the soil $\mathrm{pH}$ (Lindsay, 1972). Abou seeda et al. (1989) showed that the oxidation, generally, decreased iron and manganese content and considerably increased copper. However zinc was not affected by oxidation. Ghoneim (1996) reported that the native soil zinc decreased as the time of flooding increased. On the other hand, the availability of $\mathrm{Mn}$ and Fe increased with increasing the flooding time. Okon and Antia (2003) studied the micronutrient dynamics in some wetland soils of Nigeria and found that the amounts of $\mathrm{Fe}$ and $\mathrm{Zn}$ in these soils were strongly correlated with the clay content and with high levels of organic matter, respectively. The high levels of some micronutrients in these soil content clearly reflected their poor drainage conditions. Yongming et al. (2003) showed that copper accumulated mainly in the top layer (10 $\mathrm{cm})$ of the soil profile. Also, they showed that the reducible $\mathrm{Fe}$ and $\mathrm{Mn}$ oxide bound fraction may be more important for controlling the mobility and bio availability of $\mathrm{Cu}$, than oxidizable organic matter bound fraction in paddy soils. The availability of micronutrients is particularly sensitive to changes in soil environment. Soil factors such as organic matter, soil pH, lime content, and redox potential as well as sand, silt, and clay contents affect the available amounts of micronutrients in soil. There is also correlation among the micronutrients contents and above-mentioned properties (Chaudhari et al. 2012). This study aims to investigate the available contents of $\mathrm{Fe}, \mathrm{Mn}, \mathrm{Zn}$ and $\mathrm{Cu}$ in fish farming soils and their relation with soil properties.

\section{Materials and Methods:}

To achieve the purpose of the present study, it was necessary to select representative sites, similar in nature and fall within an area of about 100 feddans. The studied soils are located in the village No. 73, about 10 $\mathrm{km}$ to the west of El-Hamoul city, Kafr El-sheikh governorate, Egypt. Ten soil profiles were chosen according to the variation in land utilization type and the period of the land use. Another soil profile (No.1) was selected to represent a virgin soil that had not been used before.

Profiles No. 2, 3, 4 and 5 represented the soils that were used in fish farming for 5, 10, 15 and 20 years re- 
spectively whereas profiles No.6 and 7 were for soils under agricultural cultivation. Meanwhile, profiles No. 8 , and 9 represented soils that were cultivated after fish farming while, profiles No.10 and 11 were for soils that used in fish farming after cultivation, soluble cations and anions were determined in soil baste extract (Table 1).

Table (1): Land use type, some soil chemical and physical properties of the used soils.

\begin{tabular}{|c|c|c|c|c|c|c|c|c|c|c|}
\hline \multirow{2}{*}{$\begin{array}{l}\text { Profile } \\
\text { No. }\end{array}$} & \multirow[b]{2}{*}{ Land use type } & \multirow{2}{*}{$\begin{array}{c}\text { Land use } \\
\text { period } \\
\text { (year) }\end{array}$} & \multirow{2}{*}{$\begin{array}{c}\text { Water } \\
\text { table level } \\
\text { (cm) }\end{array}$} & \multicolumn{7}{|c|}{ Soluble cations and anions, $m$ mole $L^{-1}$} \\
\hline & & & & $\mathbf{N a}^{+}$ & $\mathbf{K}^{+}$ & $\mathbf{C a}^{++}$ & $\mathbf{M g}^{++}$ & $\begin{array}{l}\mathrm{HCO}_{3} \\
+\mathrm{CO}_{3}\end{array}$ & $\mathrm{Cl}^{-}$ & $\mathrm{SO}_{4}^{-}$ \\
\hline 1 & Virgin & - & 80 & 124.77 & 1.17 & 17.70 & 64.25 & 3.25 & 72.07 & 112.27 \\
\hline 2 & \multirow{4}{*}{$\begin{array}{c}\text { Fish } \\
\text { farming }\end{array}$} & 5 & 80 & 317.81 & 1.90 & 34.60 & 93.40 & 3.30 & 317.40 & 126.90 \\
\hline 3 & & 10 & 82 & 340.28 & 1.70 & 31.90 & 52.80 & 4.20 & 317.50 & 104.90 \\
\hline 4 & & 15 & 70 & 111.80 & 1.40 & 15.93 & 30.10 & 3.20 & 97.90 & 58.20 \\
\hline 5 & & 20 & 80 & 503.20 & 3.20 & 46.65 & 126.40 & 5.00 & 580.70 & 93.50 \\
\hline 6 & \multirow{2}{*}{ Cultivation } & 5 & 85 & 61.61 & 0.25 & 14.30 & 21.70 & 8.60 & 62.70 & 26.50 \\
\hline 7 & & 15 & 85 & 109.30 & 0.79 & 13.42 & 48.10 & 2.50 & 109.20 & 59.80 \\
\hline 8 & \multirow{2}{*}{$\begin{array}{l}\text { Cultivation after } \\
\text { fish farming }\end{array}$} & 10 after 10 & 85 & 489.05 & 0.38 & 11.00 & 34.50 & 5.10 & 475.00 & 54.80 \\
\hline 9 & & 5 after 10 & 85 & 463.20 & 1.00 & 11.77 & 22.82 & 5.20 & 411.00 & 82.60 \\
\hline 10 & \multirow{2}{*}{$\begin{array}{l}\text { Fish farming } \\
\text { after Cultivation }\end{array}$} & 5 after 5 & 82 & 66.76 & 1.48 & 24.14 & 83.09 & 3.20 & 23.30 & 148.90 \\
\hline 11 & & 5 after 15 & 85 & 35.70 & 0.18 & 8.30 & 20.45 & 6.15 & 42.50 & 15.70 \\
\hline
\end{tabular}

Soil samples were taken from each profile according to the morphological differentiation (FAO, 1977). Soil samples were air dried, ground, sieved through a $2-\mathrm{mm}$ sieve and stored for analysis. Particle-size distribution and fine clay $(<1 \mu)$ was separated from the coarse $(>1 \mu)$ one of soil samples was carried out using the pipette method (Klute, 1986). Soil $\mathrm{pH}$ was determined in 1:2.5 soil water suspension, at $25 \mathrm{oC}$ using a glass electrode according to Cottenie et al. (1982). Calcium and Magnesium were determined by the EDTA method (page et al., 1982). Sodium and potassium were determined by emission flam photometer, (page et al., 1982). Soluble Carbonaet and Bicarbonates were determined by using the titration method (page et al., 1982). Chloride concentration was determined using silver nitrate and potassium chromate as indicator, according to (page et al., 1982). Sulfate ion was calculated by subtracting concentration of total soluble anions and cations. Total calcium carbonate in the soil sample was determined using Collin's calcimeter and the results were calculated as $\mathrm{CaCO}_{3}$ after correcting the temperature and pressure according to Nelson (1982). Soil salinity as electrical conductivity (ECe) was determined in the saturated soil paste using Beckman Conductivity bridge, (page et al., 1982). Organic matter was determined using the modified Walkly and Black method (Jackson, 1967). Available Fe, Mn, $\mathrm{Cu}$ and $\mathrm{Zn}$ were extracted using ethylene diamine tetra-acitic acid (EDTA) as mentioned by (Cottenie et al., 1982) .All tested micronutrients 
were analyzed using atomic absorption spectrophotometer (AAS).

Results and Discussion:

1 Soil physical and chemical properties

\subsection{Particle size distribution}

Table (2) showed that the total and fine clay tended to increase in the subsurface soil in paddy soil of fish ponds. The total and fine clay was increased in the subsurface layer compared to both its upper or lower layer, of profiles No.3, and 5 which represented of soils that were used as fish ponds for 10 , and 20 years respectively. The increase magnitude reached $19.23 \%$ of the total clay in profile No. 5. Similar results were noticed by IRRI, (1987) who reported that the paddy soil profile forms a hard pan and subsoil due to accumulative clay or humus and clay. Soils which had been used as fish ponds for 5 years, exhibited a little increase in the fine clay in the subsurface soil; this increase did not exceed $1.1 \%$. However, there was a decrease in the fine clay of profile No.4, which represented the soil that was used as a fish pond for 15 years, with increasing soil depth up to $20 \mathrm{~cm}$. A noticeable high clay content occurred in the upper layer of profile No.4, could be attributed to the manner of establishment of poles of fish farms, due to excavation of ponds to about $1 \mathrm{~m}$. Regarding the soils under cultivation, the total clay also increased in the subsurface soil of profiles No.7 and 6 , but fine clay was higher in the surface and deeper layers, which may be due to agricultural practices.

On the other hand, the soils profiles No.8, and 9 which had been cultivated for 10 years after using as fish ponds had an increase in the total and fine clay with soil depth. 
Table (2): Particle-size distribution of the studied soil profiles.

\begin{tabular}{|c|c|c|c|c|c|c|c|c|c|}
\hline \multirow{3}{*}{$\begin{array}{l}\text { Land use } \\
\text { type }\end{array}$} & \multirow{3}{*}{$\begin{array}{c}\text { Land use period } \\
\text { (year) }\end{array}$} & \multirow{3}{*}{$\begin{array}{c}\text { Profile } \\
\text { No }\end{array}$} & \multirow{3}{*}{$\begin{array}{l}\text { Depth } \\
\text { cm }\end{array}$} & \multicolumn{6}{|c|}{ Particle size distribution } \\
\hline & & & & \multicolumn{2}{|c|}{\begin{tabular}{|l|} 
Clay $\%$ from the total \\
\end{tabular}} & \multirow{2}{*}{$\begin{array}{l}\text { Clay } \\
(\%)\end{array}$} & \multirow{2}{*}{$\begin{array}{l}\text { Silt } \\
(\%)\end{array}$} & \multirow{2}{*}{$\begin{array}{c}\text { Sand } \\
(\%)\end{array}$} & \multirow{2}{*}{ Soil texture } \\
\hline & & & & Coarse $>1 \mu$ & Fine $<1 \mu$ & & & & \\
\hline \multirow{22}{*}{ } & \multirow{5}{*}{ Virgin soil } & \multirow{4}{*}{1} & $0-30$ & 37.58 & 62.42 & 50.5 & 47.13 & 2.37 & Silt clay \\
\hline & & & $30-45$ & 48.67 & 51.33 & 32.25 & 59.9 & 7.85 & Silt clay loam \\
\hline & & & $45-80$ & 49.19 & 50.81 & 22.77 & 61.06 & 16.17 & Silt loam \\
\hline & & & $80-100$ & 44.38 & 55.62 & 41.43 & 56.39 & 2.18 & Silt clay \\
\hline & & \multicolumn{2}{|c|}{ W.mean } & 44.67 & 36.61 & 36.29 & 55.77 & 7.98 & \\
\hline & \multirow{4}{*}{5} & \multirow{3}{*}{2} & $0-35$ & 8.68 & 91.32 & 76.5 & 21.93 & \begin{tabular}{|l|}
1.57 \\
\end{tabular} & Clay \\
\hline & & & $35-60$ & 7.58 & 92.42 & 73.43 & 25.81 & 0.75 & Clay \\
\hline & & & $60-125$ & 28.68 & 71.32 & 67.71 & 28.3 & 3.99 & Clay \\
\hline & & \multicolumn{2}{|c|}{ W.mean } & 18.86 & 81.14 & 71.31 & 26.01 & 2.66 & \\
\hline & & \multirow{4}{*}{3} & $0-25$ & 23.81 & 76.19 & 78.65 & 17.48 & 3.87 & Clay \\
\hline & & & $25-45$ & 14.75 & 85.25 & 83.8 & 13.89 & 2.31 & Clay \\
\hline & 10 & & $45-95$ & 41.48 & 58.52 & 73.18 & 26.35 & \begin{tabular}{|l|}
0.47 \\
\end{tabular} & Clay \\
\hline & & & $95-110$ & 27.26 & 72.74 & 30.86 & 29.42 & 39.72 & Clay loam \\
\hline & & & nean & 30.67 & 69.33 & 70.58 & 22.49 & 7.05 & \\
\hline & & & $0-20$ & 8.49 & 91.51 & 67 & 31.49 & 1.51 & Clay \\
\hline & 15 & 4 & $20-45$ & 8.9 & 91.1 & 50.34 & 42.71 & 6.95 & Silt clay \\
\hline & 13 & & $45-70$ & 3.21 & 96.79 & 65.48 & 33.83 & \begin{tabular}{|l|}
0.64 \\
\end{tabular} & Silt clay \\
\hline & & & nean & 6.75 & 93.25 & 60.51 & 36.33 & 8.8 & \\
\hline & & & $0-40$ & 18.68 & 81.32 & 56.99 & 41.46 & \begin{tabular}{|l|}
1.55 \\
\end{tabular} & Silt clay \\
\hline & 20 & 5 & $40-90$ & 11.57 & 88.43 & 76.22 & 21.42 & 2.36 & Clay \\
\hline & 20 & & $90-110$ & 19.92 & 80.08 & 67.15 & 28.43 & 4.42 & Clay \\
\hline & & & nean & 15.67 & 84.33 & 67.59 & 29.98 & 2.44 & \\
\hline & & & $0-20$ & 42.39 & 57.61 & 39.7 & 55.36 & \begin{tabular}{|l|}
4.49 \\
\end{tabular} & Clay loam \\
\hline & & 6 & $20-50$ & 54.68 & 45.32 & 70.91 & 28.24 & \begin{tabular}{|l|}
0.86 \\
\end{tabular} & Clay \\
\hline & 5 & 0 & $50-95$ & 47.6 & 52.4 & 47.19 & 43.11 & 9.7 & Silt clay \\
\hline & & & $95-130$ & 48.38 & 51.62 & 51.18 & 46.38 & 2.44 & Silt clay \\
\hline 氖 & & & nean & 49.51 & 51.38 & 52.58 & 42.44 & 4.9 & \\
\hline$\stackrel{\nexists}{=}$ & & & $0-50$ & 40.32 & 59.68 & 64.68 & 26.07 & \begin{tabular}{|l|}
9.25 \\
\end{tabular} & Clay \\
\hline$\tilde{U}$ & & 7 & $50-80$ & 51.7 & 48.3 & 66.89 & 30.62 & 2.49 & Clay \\
\hline & 15 & 1 & $80-100$ & 35 & 65 & 44.4 & 41.47 & 14.13 & Silt clay \\
\hline & & & $100-120$ & 42.86 & 57.14 & 23.31 & 50.76 & 25.93 & Silt loam \\
\hline & & & nean & 42.7 & 57.14 & 54.46 & 33.89 & 11.15 & \\
\hline$\stackrel{000}{=}$ & & & $0-20$ & 15.75 & 89.25 & 23.63 & 67.35 & \begin{tabular}{|l|}
9.02 \\
\end{tabular} & Silt loam \\
\hline E्E & & 8 & $20-35$ & 15.13 & 84.87 & 72.66 & 23.22 & 4.12 & Clay \\
\hline 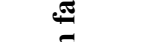 & 10 after 10 & 0 & $35-75$ & 72.03 & 27.97 & 25.75 & 71.93 & 2.32 & Silty \\
\hline $\bar{n}$ & & & $75-110$ & 80.58 & 19.42 & 20.9 & 66.04 & 13.06 & Silt loam \\
\hline 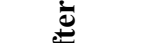 & & & nean & 56.75 & 44.11 & 30.1 & 62.58 & 7.2 & \\
\hline$\stackrel{\bar{J}}{=}$ & & & $0-30$ & 45.17 & 54.83 & 27.2 & 67.23 & \begin{tabular}{|l|}
5.57 \\
\end{tabular} & Silt loam \\
\hline 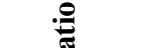 & 5 after 10 & 9 & $30-75$ & 8.33 & 91.67 & 55.52 & 40.87 & 3.61 & Clay \\
\hline 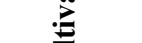 & Sallet 10 & & $75-110$ & 16.16 & 83.84 & 60.52 & 32.41 & 7.07 & Clay \\
\hline $\bar{E}$ & & & nean & 20.87 & 79.13 & 49.38 & 45.37 & 5.25 & \\
\hline & & & $0-60$ & 42.37 & 57.63 & 69.52 & 29.73 & \begin{tabular}{|l|}
0.75 \\
\end{tabular} & Clay \\
\hline$\stackrel{\Xi}{\Xi}$ & 5 after 5 & 10 & $60-80$ & 44.29 & 55.71 & 66.36 & 31.43 & 2.21 & Clay \\
\hline$\Xi$ & S diler & & $80-105$ & 15.75 & 84.25 & 70.48 & 24.37 & 5.15 & Clay \\
\hline & & & nean & 36.39 & 63.6 & 69.23 & 28.78 & 2.07 & \\
\hline$\overline{\bar{\tau}}$ & & & $0-40$ & 44.66 & 55.34 & 21.65 & 76.84 & 1.51 & Silt loam \\
\hline. & & 11 & $40-60$ & 47.58 & 52.42 & 59.56 & 31.81 & 8.63 & Clay \\
\hline 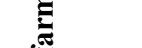 & 5 after 15 & 11 & $60-90$ & 49.86 & 50.14 & 15.77 & 82.7 & 1.53 & Silt loam \\
\hline$=$ & & & $90-110$ & 37.85 & 62.15 & 51.31 & 46.53 & 2.17 & Silt clay \\
\hline 学 & & & ean & 45.37 & 54.62 & 32.33 & 64.74 & 2.92 & \\
\hline
\end{tabular}


This increase could be attributed to the migration of fine clay downward their use as fish ponds and before to be cultivated. However the soil of profile No.10 which was used as a fish pond after its cultivation showed a high content of clay in the surface layer compared to the arable land. Generally, migration of fine clay in the soils under fish forming conditions may result in close the fine pores, of the soil leading to reduced and gleying conditions. This impact must be taken into consideration if the soil will be used as a fish pond for long time.

\subsection{Soil pH}

The $\mathrm{pH}$ values of the investigated soil profiles are recorded in Table (3). All the studied soil samples showed an alkaline soil of $\mathrm{pH}$ value. It is mainly due to the prevailed arid climatic conditions and the dominance of sodium ions in both soils and irrigation water. Using soils in fish farming remarkably decreased the soil $\mathrm{pH}$ which could be attributed to the addition of organic manure to feed fish, and it's decomposition under anaerobic conditions, and to the regular addition of superphosphate during the drying period of fish farming poles. The soils represented by profile No.5 which had been subjected to fish farming for about 20 years, showed a marked decrease in the soil $\mathrm{pH}$ (8.19 as a mean value) compared to the virgin soil of profile No.1 (pH 8.93). This may be because of the highest values of EC that were recorded in the virgin soils. In addition, data in Table (3) show a proportional increase of organic matter in the soils used as fish farms, and inversely related to the $\mathrm{pH}$ value. The highest value of organic matter (2.05\% as a mean value) had been recorded for profile No.5 which exhibited the lowest value of soil $\mathrm{pH}$ (8.19).

A lower influence of cultivation in decreasing the soil $\mathrm{pH}$ values was found in profiles No.6 and No.7, compared to that under fish farming conditions. The soils which had been subjected to the cultivation after fish farming, recorded lower $\mathrm{pH}$ values compared to those cultivated without fishering. Turning the cultivated soils into fish farming as in profiles No. 10 and No.11, caused a noticeable decrease in soil $\mathrm{pH}$. Five year fishering after cultivation for 5 years as in profile No.10, recorded the a lower soil $\mathrm{pH}$ value of 8.33 while this fishering time soils, after 15 years of cultivation as in profile No.11, recorded $\mathrm{pH}$ value of 8.82 . Generally, there were lower the soil $\mathrm{pH}$ values in the soils which have been used as fish ponds compared to those of the cultivated soils. 
Table (3): Some chemical properties of the soil profiles under study.

\begin{tabular}{|c|c|c|c|c|c|c|c|}
\hline \multirow{2}{*}{$\begin{array}{c}\text { Land us } \\
\text { type }\end{array}$} & \multirow{2}{*}{$\begin{array}{c}\text { Land use } \\
\text { period } \\
\text { (year) }\end{array}$} & \multirow[b]{2}{*}{ Profile No } & \multirow{2}{*}{$\begin{array}{l}\text { Depth } \\
\text { (cm) }\end{array}$} & \multicolumn{4}{|c|}{ Soil property } \\
\hline & & & & pH & $\begin{array}{l}\text { O.M } \\
(\%)\end{array}$ & $\begin{array}{c}\text { ECe } \\
\text { (dS m-1) }\end{array}$ & $\mathrm{CaCO}_{3}$ \\
\hline \multirow{5}{*}{\multicolumn{2}{|c|}{ Virgin soil }} & \multirow{4}{*}{1} & $0-30$ & 8.93 & 0.88 & 44.8 & 1.50 \\
\hline & & & $30-45$ & 8.97 & 0.51 & 8.81 & 0.46 \\
\hline & & & $45-80$ & 9.12 & 0.34 & 9.20 & 1.34 \\
\hline & & & $80-100$ & 8.61 & 0.51 & 12.45 & 0.88 \\
\hline & & & & 8.93 & 0.56 & 20.47 & 1.16 \\
\hline \multirow{17}{*}{ 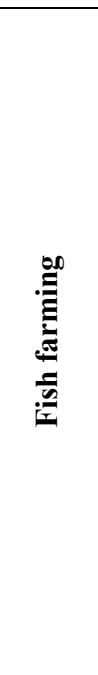 } & \multirow{4}{*}{5} & \multirow{3}{*}{2} & $0-35$ & 8.41 & 0.76 & 28.21 & 1.14 \\
\hline & & & $35-60$ & 8.30 & 0.85 & 44.40 & 1.01 \\
\hline & & & $60-125$ & 8.46 & 0.68 & 53.00 & 1.14 \\
\hline & & \multicolumn{2}{|c|}{ W.mean } & 8.41 & 0.74 & 44.33 & 1.11 \\
\hline & \multirow{5}{*}{10} & \multirow{4}{*}{3} & $0-25$ & 8.30 & 0.51 & 40.20 & 0.88 \\
\hline & & & $25-45$ & 8.42 & 1.19 & 55.90 & 2.20 \\
\hline & & & $45-95$ & 8.36 & 0.93 & 45.50 & 0.35 \\
\hline & & & $95-110$ & 8.72 & 0.51 & 17.50 & 2.20 \\
\hline & & \multicolumn{2}{|c|}{ W.mean } & 8.41 & 0.82 & 42.36 & 1.06 \\
\hline & \multirow{4}{*}{15} & \multirow{3}{*}{4} & $0-20$ & 8.35 & 2.72 & 26.65 & 2.31 \\
\hline & & & $20-45$ & 8.86 & 0.93 & 9.31 & 3.81 \\
\hline & & & $45-70$ & 9.16 & 2.29 & 12.31 & 7.04 \\
\hline & & \multicolumn{2}{|c|}{ W.mean } & 8.82 & 1.93 & 15.33 & 4.54 \\
\hline & & & $0-40$ & 8.20 & 1.46 & 32.21 & 2.64 \\
\hline & & 5 & $40-90$ & 8.18 & 2.38 & 76.39 & 4.44 \\
\hline & 20 & & $90-110$ & 8.18 & 2.38 & 110.7 & 3.78 \\
\hline & & & & 8.19 & 2.05 & 66.56 & 3.66 \\
\hline \multirow{10}{*}{ 竞 } & \multirow{5}{*}{5} & & $0-20$ & 8.74 & 1.19 & 5.90 & 2.95 \\
\hline & & 6 & $20-50$ & 8.96 & 0.85 & 5.72 & 1.45 \\
\hline & & 0 & $50-95$ & 9.10 & 0.68 & 7.00 & 2.33 \\
\hline & & & $95-130$ & 9.10 & 0.59 & 19.81 & 3.83 \\
\hline & & & & 9.01 & 0.77 & 9.98 & 2.62 \\
\hline & & & $0-50$ & 8.16 & 1.76 & 20.20 & 0.92 \\
\hline & & & $50-80$ & 8.09 & 1.02 & 17.50 & 0.44 \\
\hline & 15 & t & $80-100$ & 9.41 & 0.68 & 7.23 & 2.02 \\
\hline & & & $100-120$ & 9.28 & 0.76 & 9.27 & 1.32 \\
\hline & & & & 8.54 & 1.22 & 15.54 & 1.05 \\
\hline & & & $0-20$ & 8.45 & 1.53 & 8.54 & 2.42 \\
\hline & & 8 & $20-35$ & 8.26 & 2.12 & 63.30 & 1.36 \\
\hline$\overline{0}$ & 10 after 10 & 8 & $35-75$ & 8.55 & 2.29 & 58.18 & 1.76 \\
\hline 䒕 & & & $75-110$ & 8.89 & 0.08 & 67.34 & 0.53 \\
\hline$\tilde{\bar{E}}$ & & & & 8.60 & 1.42 & 52.76 & 1.43 \\
\hline 墕 & & & $0-30$ & 8.51 & 0.98 & 69.14 & 2.51 \\
\hline$\sum^{\infty}$ & 5 after 10 & 9 & $30-75$ & 8.71 & 1.31 & 39.42 & 3.17 \\
\hline$\underline{E}$ & 5 atter 10 & & $75-110$ & 8.67 & 1.36 & 46.64 & 3.34 \\
\hline & & & & 8.64 & 1.24 & 49.82 & 3.04 \\
\hline & & & $0-60$ & 8.40 & 0.91 & 18.40 & 1.23 \\
\hline U & 5 after 5 & 10 & $60-80$ & 8.11 & 1.19 & 19.94 & 2.20 \\
\hline$\grave{\Xi}$ & 5 anter 5 & & $80-105$ & 8.36 & 1.02 & 12.50 & 0.70 \\
\hline పี & & & & 8.33 & 0.99 & 17.28 & 1.29 \\
\hline ט. & & & $0-40$ & 8.91 & 1.2 & 3.00 & 2.42 \\
\hline 馬 & & 11 & $40-60$ & 9.01 & 1.76 & 7.64 & 1.98 \\
\hline$\Xi$ & 5 after 15 & 11 & $60-90$ & 8.91 & 0.85 & 7.00 & 1.14 \\
\hline$=$ & & & $90-110$ & 8.32 & 0.91 & 11.15 & 2.64 \\
\hline 坣 & & & & 8.82 & 1.15 & 6.42 & 2.03 \\
\hline
\end{tabular}

These results are in an agreement with those obtained by Aboulrous et al. (1981) who reported that the soil $\mathrm{pH}$ decreased upon flooding until reaching slightly acidic values. It could be concluded that using the soils in the north delta as fish farms may decrease the $\mathrm{pH}$ of the soil, which may improve the solubility of some nutrients such phosphorus and some micronutrients.

\subsection{Soil salinity}

The virgin soil showed high accumulation of salts on the surface layer, where as its ECe reached 44.80 $\mathrm{dS} / \mathrm{m}$ (Table 3 profile No.1). It could 
be attributed to the upward movement of saline ground water by the capillary rise, which represents an ascending salt profile. So, it is worthy to mention that using soils under any type of land use may protect them from deterioration.

Moreover, the soils which had been subjected to fish ponds, resulted in redistribution of salts along the depth of soil profile. There was a marked decrease in the ECe values in the upper layer of profiles No. 2, 3, and 5 (Table 3). The continuous flooding with water caused the salts to remove from the upper layer down ward the soil profiles resulting in increase in the soil salinity in the bottom of the soil profiles. Cultivating the soils caused a sharp decrease in soil salinity as it is shown in profile No.6. The traditional management and the irrigation system that are used in the cultivated soils may lead to a type of intermittent leaching which accelerates removing the salts and improving the soil salinity, particularly with the prevailed rice cultivation in this area. Also, cultivating the soils even after fish farming exhibited lower decrease in the ECe values as it is shown in profiles No.8, and 9 where the mean ECe values reached $49.82 \mathrm{dS} / \mathrm{m}$ (profile No.9).Moreover, the soils which were turned from cultivation to fish farming still had lower ECe values as it is found in profiles No. 10 and 11 where the ECe values varied from 3.00 to $18.40 \mathrm{dS} / \mathrm{m}$

\subsection{Total calcium carbonate $\left(\mathrm{CaCO}_{3}\right)$}

Table (3) shows that the distribution of total calcium carbonate varied widely among the investigated soil profiles. The amounts of total calcium carbonate in the soils that were used as fish ponds (profiles No.
$2,3,4$, and 5) were higher than in the virgin soil (profile No.1). The total $\mathrm{CaCO}_{3}$ in the fish farming soils increased with increasing the land use period from 5 to 15 years, where as the total $\mathrm{CaCO}_{3}$ values varied from 1.11 to $4.54 \%$. The magnitude increase of $\mathrm{CaCO}_{3}$ was relatively lower after 20 years of fishering (3.66\%), compared to after 15 years of fish farming. Flooding the soil with water as in fish farming may cause differential mobility of the mono and divalent cations in those soils. It means that the rate of removing $\mathrm{Na}^{+}$is higher than $\mathrm{Ca}^{2+}$ and $\mathrm{Mg}^{2+}$, therefore, $\mathrm{CaCO}_{3}$ may precipitate under these conditions. These results agree with those reported by Abo Waly, et al. (1994), who pointed out that using the soil as fish farming may cause $\mathrm{Na}^{+}$to remove more than $\mathrm{Ca}^{++}$, wherever, $\mathrm{CaCO}_{3}$ may precipitate. The total $\mathrm{CaCO}_{3}$ under fish farming land use was increased with increasing the soil depth. It could be attributed to the mobility of $\mathrm{Ca}\left(\mathrm{HCO}_{3}\right)_{2}$ during the process of decarbonation due to flooding, and its downwards the soil profile and then, its precipitation as $\mathrm{CaCO}_{3}$ due to the carbonation process.

On the other hand, the total $\mathrm{CaCO}_{3}$ in the arable soil was lower than total $\mathrm{CaCO}_{3}$ in soils under cultivation. The total $\mathrm{CaCO}_{3}$ in soils under cultivation decreased from 2.62 to $1.05 \%$ with increasing land use period from 5 to 15 years (Table 3 ). The total $\mathrm{CaCO}_{3}$ of the soils under cultivation was higher in deeper layers than in surface ones. The soils which had been cultivated for 5 years after 10 year use as fish ponds showed an increase in total $\mathrm{CaCO}_{3}$, as it is shown in profile No.9, where as the total $\mathrm{CaCO}_{3}$ value reached $3.04 \%$. 
The total $\mathrm{CaCO}_{3}$ of the soil represented by profile No.8 which had been subjected to cultivation for 10 years after 10 year use as fish ponds was little higher than that of the soils represented by profile No.9. The results also, showed that the total $\mathrm{CaCO}_{3}$ in profile No. 11 representing the soil were used as fish ponds for 5 years after 15 years of cultivation was higher than that of profile No.10 that had been subjected to fish farming for 5 years after 5 years of cultivation.

Generally, cultivating the soil before its use in fish farming increases the total $\mathrm{CaCO}_{3}$ in the soil comparison with when the soil is used in fish farming only. Whereas the total $\mathrm{CaCO}_{3}$ of profiles No.10 and 11 was higher than that of profile No.2.

\subsection{Soil organic matter (OM)}

The soil organic matter (OM) content varied among the different studied soil profiles (Table 3). The virgin soil had the lowest values of OM (0.34-0.88\%) with substantial decrease with depth. The soils under fish forming contained relatively higher contents of OM, compared with those under other land use types or the virgin soil. These results are in an agreement with Nashy (1995) who recorded a noticeable increase in the organic matter content of the soil fish farming, whereas it increased from $1.22 \%$ at the begging of the study to $1.44 \%$ after the second season of fish growth, and reached the maximum $(2.2 \%)$ in the third season.

The results also indicated that the soil organic matter increased with increasing the land use period of the fish farming, resulting an increase in the organic matter values from 0.73 to $2.05 \%$ with increasing land use period from 5 (profile No.2) to 20 years (profile No.5). This increase could be attributed to the regular addition of organic matter to feed fish and to the prevailed anaerobic conditions that could delete OM decomposition. The highest value of organic matter was obtained in the surface soil layer, which had been used in fish farming for 15 years, (profile No.4). A remarkable increase of organic matter was recorded in the deeper layers of some profiles that may be due to the presence of decomposed burred organic matter. In addition, the high content of organic matter in deepest layers is probably, because of dissolving the humus as sodium humate and its movement down ward the soil profile.

\section{Available micro nutrients:}

The available micronutrients which had been extracted by EDTA as affected by and land use type and time period are presented in Table (4). The distribution of the available investigated micronutrients in the studied profiles were in the decreasing order of $\mathrm{Mn}>\mathrm{Fe}>\mathrm{Cu}>\mathrm{Zn}$.

\subsection{Available iron (Fe)}

Table (4) indicated that the available $\mathrm{Fe}$ in the soils under fish farming (flooding conditions) was higher than in the virgin soil. There was an exception in profile No.4 which represented the soils that were used in of fish farming for 15 years, where available Fe was lower than in the virgin soil (profile No.1). Moreover, the available $\mathrm{Fe}$ in the soil that was used in fish farming increased with increasing the duration of flooding where of the available $\mathrm{Fe}$ increased from 157.9 to $319.90 \mathrm{mg} / \mathrm{kg}$ when the durations of fish farming increased from 5 to 20 years.

The available $\mathrm{Fe}$ in fish farming soils also increased with soil depth, It 
may be attributed to the higher content of fine clay in deeper layers (Table4). However the available $\mathrm{Fe}$ in profile No.4 which represented the soil that was used in fish forming for
15 years was higher in the surface layer which it was probably to its high content of organic matter $(2.72 \%)$ in the surface layer (Table 4).

Table (4): Effect of cultivation and fish farming land use and its time period on the available $\mathrm{Fe}, \mathrm{Mn}, \mathrm{Cu}$ and $\mathrm{Zn}$.

\begin{tabular}{|c|c|c|c|c|c|c|c|}
\hline \multirow{2}{*}{$\begin{array}{l}\text { Land use } \\
\text { type }\end{array}$} & \multirow{2}{*}{\begin{tabular}{|c|}
$\begin{array}{c}\text { Land use pe- } \\
\text { riod } \\
\text { (year) }\end{array}$ \\
\end{tabular}} & \multirow[b]{2}{*}{ Profile No } & \multirow[b]{2}{*}{ Depth (cm) } & \multicolumn{4}{|c|}{ Micronutrent (ppm) } \\
\hline & & & & $\mathrm{Fe}$ & Mn & $\mathrm{Cu}$ & $\mathbf{Z n}$ \\
\hline \multirow{5}{*}{\multicolumn{2}{|c|}{$\overline{0}$}} & \multirow{4}{*}{1} & $0-30$ & 137.00 & 226.16 & 5.50 & 2.30 \\
\hline & & & $30-45$ & 325.00 & 397.28 & 6.00 & 0.52 \\
\hline & & & $45-80$ & 140.50 & 184.40 & 3.95 & 0.58 \\
\hline & & & $80-100$ & 42.50 & 316.96 & 6.30 & 0.47 \\
\hline & & W.n & ean & 147.35 & 255.40 & 5.14 & 1.06 \\
\hline \multirow{17}{*}{ 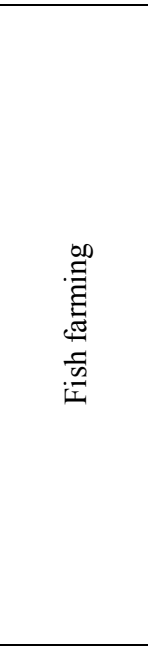 } & \multirow{4}{*}{5} & \multirow{3}{*}{2} & $0-35$ & 62.50 & 652.00 & 6.00 & 1.39 \\
\hline & & & $35-60$ & 233.00 & 470.56 & 9.15 & 1.69 \\
\hline & & & $60-125$ & 215.00 & 452.90 & 8.70 & 1.71 \\
\hline & & \multicolumn{2}{|c|}{ W.mean } & 157.90 & 512.18 & 8.03 & 1.62 \\
\hline & \multirow{5}{*}{10} & \multirow{4}{*}{3} & $0-25$ & 318.00 & 859.60 & 7.05 & 2.38 \\
\hline & & & $25-45$ & 320.50 & 480.08 & 15.90 & 0.77 \\
\hline & & & $45-95$ & 333.50 & 881.76 & 9.10 & 2.03 \\
\hline & & & $95-110$ & 76.00 & 166.48 & 10.40 & 0.69 \\
\hline & & \multicolumn{2}{|c|}{ W.mean } & 292.50 & 706.15 & 10.04 & 1.69 \\
\hline & \multirow{4}{*}{15} & \multirow{3}{*}{4} & $0-20$ & 212.50 & 355.44 & 6.05 & 0.72 \\
\hline & & & $20-45$ & 129.50 & 370.72 & 4.60 & 0.53 \\
\hline & & & $45-70$ & 87.00 & 248.48 & 4.90 & 0.30 \\
\hline & & \multicolumn{2}{|c|}{ W.mean } & 138.04 & 322.70 & 5.12 & 0.50 \\
\hline & \multirow{4}{*}{20} & \multirow{3}{*}{5} & $0-40$ & 202.00 & 343.68 & 11.80 & 1.72 \\
\hline & & & $40-90$ & 397.00 & 352.20 & 11.10 & 1.56 \\
\hline & & & $90-110$ & 363.00 & 353.20 & 10.90 & 2.13 \\
\hline & & W.n & ean & 319.90 & 349.30 & 11.32 & 1.72 \\
\hline & & & $0-20$ & 220.00 & 425.20 & 11.00 & 0.48 \\
\hline & & 6 & $20-50$ & 253.00 & 512.08 & 10.00 & 1.08 \\
\hline & 5 & 0 & $50-95$ & 92.00 & 552.56 & 7.20 & 0.93 \\
\hline & & & $95-130$ & 117.00 & 508.24 & 7.20 & 0.53 \\
\hline 产 & & W.n & ean & 155.58 & 511.69 & 8.43 & 0.78 \\
\hline 恶 & & & $0-50$ & 44.50 & 513.84 & 9.00 & 0.96 \\
\hline & & 7 & $50-80$ & 154.00 & 280.40 & 6.00 & 1.38 \\
\hline & 15 & 1 & $80-100$ & 73.00 & 296.96 & 5.60 & 0.81 \\
\hline & & & $100-120$ & 49.00 & 510.96 & 3.00 & 0.59 \\
\hline & & W.n & ean & 77.37 & 418.85 & 6.70 & 0.98 \\
\hline & & & $0-20$ & 14.50 & 20.64 & 8.00 & 0.05 \\
\hline$\overline{\mathrm{w}}$ & & & $20-35$ & 262.50 & 467.12 & 4.70 & 2.15 \\
\hline & 10 after 10 & 8 & $35-75$ & 148.00 & 333.92 & 7.40 & 0.60 \\
\hline 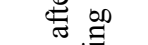 & & & $75-110$ & 174.50 & 573.52 & 5.40 & 0.71 \\
\hline है & & W.n & ean & 147.80 & 371.40 & 6.50 & 0.74 \\
\hline 㓂 & & & $0-30$ & 78.50 & 389.44 & 8.40 & 0.66 \\
\hline E & & 9 & $30-75$ & 218.50 & 435.92 & 6.10 & 1.21 \\
\hline Uే & 5 anter iv & & $75-110$ & 188.50 & 449.60 & 4.90 & 0.68 \\
\hline & & W.n & ean & 170.77 & 427.60 & 6.35 & 0.89 \\
\hline & & & $0-60$ & 38.00 & 377.92 & 6.80 & 0.68 \\
\hline $\bar{Z}$ & 5 after 5 & 10 & $60-80$ & 252.50 & 376.56 & 16.00 & 0.97 \\
\hline$\vec{\Delta}$ & Saller & & $80-105$ & 270.50 & 387.20 & 8.90 & 0.83 \\
\hline बूँ ซ & & W.n & ean & 134.21 & 379.87 & 9.05 & 0.77 \\
\hline 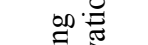 & & & $0-40$ & 68.50 & 379.20 & 7.70 & 0.54 \\
\hline & & & $40-60$ & 234.00 & 504.88 & 16.10 & 0.89 \\
\hline 氙 & 5 after 15 & 11 & $60-90$ & 75.00 & 466.08 & 5.00 & 0.70 \\
\hline ज्ञ & & & $90-110$ & 80.00 & 410.64 & 3.60 & 0.80 \\
\hline$=$ & & W.n & ean & 102.45 & 431.46 & 7.75 & 0.69 \\
\hline
\end{tabular}


These results are in coincide with those of Okon and Antia (2003) who found that the amounts of soil $\mathrm{Fe}$ were strongly correlated to the clay and $\mathrm{OM}$ contents in some wetland soils. Available $\mathrm{Fe}$ in the soils which had been cultivated for 5 , and 15 years decreased with increasing the duration of cultivation (Table 4). The available $\mathrm{Fe}$ in the soils which had been cultivated for 15 years (profile No.7) was lower than in the virgin soil (profile No.1). It could be due to the uptake of available $\mathrm{Fe}$ by the growen crops.

The soils which had been cultivated for 10 years after 10 years of fish farming contained almost the same level of available $\mathrm{Fe}$ as the virgin soil as it is shown in profile No.8, where the available Fe reached 147.8 $\mathrm{mg} / \mathrm{kg}$ (Table 4). The available Fe values profile No. 9 which represented the soil that had been subjected to cultivation for 5years after 10 years of fish farming were slightly higher than in profile No.8.

Regarding the soils which were used in fish farming for 5 years after 5 years of cultivation profile No.10, there was an increase in the available Fe compared to the virgin soil. The variations in available $\mathrm{Fe}$ in these soils were higher compared to those of available $\mathrm{Fe}$ in the soils that were used in fish forming for 5 years after

Table 5: Correlation coefficients ( $r$ ) of the available $\mathrm{Fe}, \mathrm{Mn}, \mathrm{Cu}$ and $\mathrm{Zn}$ and some properties of the studied soils.

\begin{tabular}{|c|c|c|c|c|c|c|c|}
\hline Micronutrient & $\mathbf{p H}$ & $\mathbf{O M}$ & $\mathbf{E C}$ & $\mathbf{C a C O 3}$ & Sand & Silt & Clay \\
\hline $\mathbf{F e}$ & $-0.352^{*}$ & 0.263 & $0.516^{* *}$ & -0.006 & $-0.318^{* *}$ & -0.351 & $0.435^{* *}$ \\
\hline $\mathbf{M n}$ & -0.100 & -0.213 & 0.170 & $-0.316^{*}$ & -0.253 & -0.290 & $0.356^{*}$ \\
\hline $\mathbf{C u}$ & $-0.353^{*}$ & 0.223 & 0.165 & 0.051 & -0.175 & -0.126 & 0.178 \\
\hline $\mathbf{Z n}$ & $-0.444^{* *}$ & 0.099 & $0.562^{* *}$ & -0.222 & -0.272 & $-0.482^{* *}$ & $0.536^{* *}$ \\
\hline
\end{tabular}

**. Correlation is significant at the 0.01 level

*. Correlation is significant at the 0.05 level
15 years of cultivation profile No.11, where the available $\mathrm{Fe}$ in those soils reached $102.45 \mathrm{mg} / \mathrm{kg}$.

The available Fe showed negatively significant correlations with soil $\mathrm{pH}(\mathrm{r}=-0.352)$, sand $(\mathrm{r}=$ $0.318)$ and silt $(\mathrm{r}=-0.351)$ content and positively significant correlations content $(r=0.435)$ (Table 5).

This result agree with these obtained by Chaudhari et al. (2012) who found that the available Fe showed a highly positive correlation with the electrical conductivity of soil (EC) (r $=0.969278)$. Their results also showed negatively significant correlation $(\mathrm{r}=-0.5752)$ between the available $\mathrm{Fe}$ with $\mathrm{pH}$ was found. However, nonsignificantly positive correlation was found between the available $\mathrm{Fe}$ and the organic carbon in the soil.

\subsection{Available manganese (Mn)}

The available $\mathrm{Mn}$ showed the highest level of the investigated micronutrients in the studied soils (Table 4). The available $\mathrm{Mn}$ in profiles No. 2, 3,4,and 5, which represent the soils that were used in fish farming for 5,10,15 and 20 years ranged between 322.7 and $706.15 \mathrm{mg} / \mathrm{kg}$ as mean values. Generally, the available $\mathrm{Mn}$ in fish forming soils was higher than in the virgin soils $(255.4 \mathrm{mg} / \mathrm{kg})$. with the ECe $(r=0.561)$ and clay 
Fish farming conditions probably may increase the solubility $\mathrm{Mn}$ compounds in the soil resulting in toxic level of Mn. Using the soil in fish farming for 10 years caused the available $\mathrm{Mn}$ to increase in the surface layer to a level of $859.6 \mathrm{mg} / \mathrm{kg}$ (profile No.3). These results are in an agreement with those of Abo Waly et al. (1995) who reported that the submergence conditions were largely favored and induced $\mathrm{Mn}$ and Fe solubility to levels that became toxic to the plants under the submergence regime of impeded drainage as in growing rice.

The available $\mathrm{Mn}$ in the soils under fish forming increased with increasing the land use period, whereas the available $\mathrm{Mn}$ increased from 512.18 to $706.15 \mathrm{mg} / \mathrm{kg}$ with increasing the land use period from 5 to 10 years (Table 4). However, increasing the land use period to 15 and 20 years exhibited a noticeable decrease in the available $\mathrm{Mn}$ to 322.7 and 349.3 $\mathrm{mg} / \mathrm{kg}$, respectively, as in profile No. 4 , and 5 respectively. The available $\mathrm{Mn}$ in the soils under fish forming of profile No. 2 and 4 was relatively high that may be attributed to the high clay content in these soil (Table 2).

Increasing the duration period of cultivation from 5 to 15 years caused a decrease in the available $\mathrm{Mn}$ (Table 4). The values decreased from $511.69 \mathrm{mg} / \mathrm{kg}$ in profile No. 6 to $418.85 \mathrm{mg} / \mathrm{kg}$ in profile No.7 as mean values. This decrease could be related to the agricultural practices and the aerobic conditions induced management of soils.

A high increase of the available Mn was recorded in the upper layer $(0-50 \mathrm{~cm})$ of profile No.7, where as its level it reached $513.84 \mathrm{mg} / \mathrm{kg}$. The relatively high content of organic matter in this layer $(1.76 \%)$, organic manuring as well as fertilization could be related to this increase.

Distribution of available Mn with depth was relatively homogeneous in the subsurface layers in profile No.6, which it reflects the young age of this profile that had been cultivated for only 5 years. The soils which had been cultivated for 10 years after 10 years of fish farming showed a decrease in the available Mn compared to the virgin soil, whereas the available $\mathrm{Mn}$ value reached $371.4 \mathrm{mg} / \mathrm{kg}$ as it shown in profile No.8. Regarding of soils which had been used as fish forming for 5 years after 5 years of cultivation profile No.10 there was an increase in the available Mn compared to the virgin soil. The available $\mathrm{Mn}$ in these soils reached 379.87 $\mathrm{mg} / \mathrm{kg}$ and increased with soil depth. The variation in the available $\mathrm{Mn}$ of these soils was little higher compared to that of these soils which had been used as fish farming for 5 years after 15 years of cultivation profile No.11.

The available $\mathrm{Mn}$ in these soil showed significantly negative correlation with $\mathrm{CaCO}_{3}(\mathrm{r}=0.316)$ and a significantly positive correlation with clay content $(r=0.356)$. However, it had there a negative but not significant correlation with soil $\mathrm{pH}(\mathrm{r}=$ $0.100)$, as well as organic matter $(\mathrm{r}=$ $-0.213)$, sand $(\mathrm{r}=-0.253)$ and silt $(\mathrm{r}=$ 0.290 ) contents (Table 5).

\subsection{Available copper $(\mathrm{Cu})$}

The soils under fish farming (paddy soil conditions) revealed an increase in the available $\mathrm{Cu}$ compared to the virgin soil (Table 4). The highest value of available $\mathrm{Cu}$ in the studied soil was recorded for the soils under fish farming. Copper one may be bound to soil organic matter, and Mn 
oxides and clay minerals of these soils in an available form. Yongming et al. (2003) showed that the reducible $\mathrm{Fe}$ and $\mathrm{Mn}$ oxide bound fraction may be more important for controlling the mobility and bioavailability of $\mathrm{Cu}$ than the oxidizable organic matter bound fraction in paddy soils. The available $\mathrm{Cu}$ in the soils of fish forming increased with the time of land use period (Table 4). The available $\mathrm{Cu}$ in the soils under fish forming was increased from $8.03 \mathrm{mg} / \mathrm{kg}$ to 10.04 and $11.32 \mathrm{mg} / \mathrm{kg}$ with increasing the land use period of fish forming from 5 to 10 and 20 years, respectively.

There was an exception in profile No.4 that represented the soils that were used in fish forming for 15 years, where the available $\mathrm{Cu}$ was lower than in profile No.3 which represented the soils that were used in fish forming for 10 years. It could be due to the relatively lower content of clay in profile No.4. The available $\mathrm{Cu}$ was high in the upper layer of profiles No. 4 and 5 it may be related to the presence of high content of organic matter in the surface layer of profile No. 4 Table (2) whereas in profile No. 5, the copper is probably associated with oxides of $\mathrm{Fe}$ and $\mathrm{Mn}$. Increasing the available $\mathrm{Cu}$ with depth may be related to the distribution of clay.

Regarding the available $\mathrm{Cu}$ in profiles No. 6 and 7 which represented the soils that were cultivated for 5 and 15 years respectively was higher than that of the virgin soil (profile No1). The available $\mathrm{Cu}$ was also higher in the cultivated soils (profiles No. 6 and7) than that profiles No.2 and 4 which represented the soils used as fish farming for 5, and 15 years respectively.
The available $\mathrm{Cu}$ in cultivated soils decreased with soil depth, whereas the highest available $\mathrm{Cu}$ values were recorded in the surface layer. Similar results were noticed by Yongming et al. (2003) who reported that copper accumulated mainly in the top layer $(10 \mathrm{~cm})$ of soil profile. Although the cultivation use period of was increased form profile No. 6, to profile No.7, the available $\mathrm{Cu}$ did not exhibit a corresponding increase. It may be due to its uptake by the growing plants.

The soils which had been cultivated for 10 years after 10 years of fish farming showed an increase in the available $\mathrm{Cu}$ compared to the virgin soil. Whereas in the available $\mathrm{Cu}$ reached $6.50 \mathrm{mg} / \mathrm{kg}$ in profile No.8. The variation of available $\mathrm{Cu}$ values in these soils was higher than these of the soils subjected to cultivation for 5 years after 10 years of fish farming profile No.9. The available $\mathrm{Cu}$ in profile No.9 reached $6.35 \mathrm{mg} / \mathrm{kg}$. The available $\mathrm{Cu}$ in both profiles No. 8 , and 9 decreased with soil depth.

The soils which were used in fish farming for 5 years after 5 years of cultivation had also an increase in the available $\mathrm{Cu}$ compared to either the virgin soil or the soil which had been used in fish farming for 5 years only (profile No.2). The available $\mathrm{Cu}$ increased in these soils also with soil depth. Similar results were found in the soils which had been used in fish farming for 5 years after for 15 years of cultivation, whereas the available $\mathrm{Cu}$ reached $7.75 \mathrm{mg} / \mathrm{kg}$.

There was a significant negative correlation between the available $\mathrm{Cu}$ and soil $\mathrm{pH}$ soil $(\mathrm{r}=-0.353)$ (Table $5)$. This result coincided well with those obtained by Chaudhari et al. (2012). They found that the available 
$\mathrm{Cu}$ was negatively correlated to soil $\mathrm{pH}(\mathrm{r}=-0.306)$ and positively but not significantly correlated to each of organic matter $(r=-0.223)$, silt $(r=-$ $0.126)$, sand $(\mathrm{r}=-0.175)$ and clay $(\mathrm{r}=$ $-0.178)$ content.

\subsection{Available zinc (Zn)}

Table (4) revealed that the soils under fish farming contained highest amounts of available $\mathrm{Zn}$ in the studied soils. The high values were found in the deeper layers of profiles No. 2 and 5 which represented the soils that were used in fish farming for 5 and 20 years respectively, while, the highest values were found in the surface layer of profiles No.3, and 4 which represented the soils that were used in fish farming for 10 and 15 years respectively, it could be ascribed to the distribution manner of organic matter and/or clay content.

The available $\mathrm{Zn}$ in profiles No. 6 and 7 which represented the soils that were cultivated for 5 and 15 years were lower than that of both virgin and fish farming soils (Table 4). The available $\mathrm{Zn}$ in the soils that were under cultivation increased with increasing the of land use time period whereas, the available $\mathrm{Zn}$ increased from 0.78 to $0.98 \mathrm{mg} / \mathrm{kg}$ as mean values in the soil represented by profiles No. 6 and 7 respectively. There was a remarkable relationship between the available $\mathrm{Zn}$ and the soil $\mathrm{pH}$ under the condition of cultivation. Decreasing the soil $\mathrm{pH}$ from 9.01 in profile No. 6 to 8.59 in profile No 7(Table 3) caused an increase in the available $\mathrm{Zn}$ from $0.78 \mathrm{mg} / \mathrm{kg}$ in profile No. 6 to $0.98 \mathrm{mg} / \mathrm{kg}$ in profile No.7 (Table 4). These results are in an agreement with Anderson and Christensen (1988) who reported that the solubility of $\mathrm{Zn}$ in the soil decreased as the soil $\mathrm{pH}$ increase and the total concen- tration of $\mathrm{Zn}$ in the soil solution decreased about 100 fold as the soil $\mathrm{pH}$ increased from 4.4 to $7.5 \mathrm{mg} / \mathrm{kg}$.

The soils which had been cultivated for 10 years after for 10 years of fish farming caused a decrease in the available $\mathrm{Zn}$ compared to the virgin soil. As it is shown in profile No. 8 , where the available $\mathrm{Zn}$ reached $0.74 \mathrm{mg} / \mathrm{kg}$. The variation of available $\mathrm{Zn}$ was little higher than that of profile No. 9, which had been subjected to cultivation for 5 years after 10 years of fish farming.

The soils which had been changed from cultivation to fish farming as in profiles No.10 and 11 showed a little decrease in the available $\mathrm{Zn}$ compared to either virgin soils or fish farming only. Cultivating the soil may consume the native soil $\mathrm{Zn}$ whereas $\mathrm{Zn}$ fertilization is not familiar under these types of cultivation

The available $\mathrm{Zn}$ was significantly negative correlated with the soil $\mathrm{pH}$ soil $(\mathrm{r}=-0.444)$ and with silt content $(\mathrm{r}=-0.482)$ and showed positive correlation with EC of the soil $(r=0.562)$ and with the clay content $(\mathrm{r}=0.536)$. These results were well agreed with those obtained by Chaudhari et al. (2012). They stated that there was negative correlation $(\mathrm{r}$ $=-0.306$ ) between the available $\mathrm{Zn}$ and the $\mathrm{pH}$ of soil, but a high correlation $(r=0.9856)$ was reported between the available $\mathrm{Zn}$ and electrical conductivity of soil.

\section{References:}

AbouSeeda, M.; Soliman, A.K. and Resheed, M. (1989). The influence of redox potential and $\mathrm{H}$ on the transfer of heavy metals from the solids to liquid phase in sewage sludge.Egypt, J. Soil Sci. Special Issue, pp. 323-332. Aboulroos, S.A.; Awadallah, E.A. and Taha, S.A. (1981).Effect of 
flooding and clover straw addition on the redox potential, $\mathrm{pH}$ and concentration of manganese in some soils.Alexandria, Sci., Exch. Vol. 2 No. 2, 147-160.

Abo-Waly, M.E.; Ramadan, S.A. and Ali, R.A. (1994). The influence of fish farming on clayey salt affected soils. J. Agric. Sci. Mansoura Univ, 19(1): 387-400.

Abo-Waly, M.E.; Rezk, M.M.; Ramadan, S.A. and ElShahawy, M.I. (1995).Pedogenic distribution of $\mathrm{Fe}$ and $\mathrm{Mn}$ forms in relation to different depositional environments and development of some Egyptian soils. J. Agric. Sci. Mansoura Univ. 20(4): 1865- 1877.

Anderson, R.R. and Christensen, T.H. (1988).Distribution coefficients of $\mathrm{Cd}, \mathrm{Co}, \mathrm{Ni}$ and $\mathrm{Zn}$ in soils. J. Soil Sci. 39, 15-22.

Chaudhari .P. R, D. V. Ahire and Vidya D. Ahire (2012). Correlation between Physico-chemical properties and available nutrients in sandy loam soils of Haridwar. J. Chem. Bio. Phy. Sci. Sec. C, 2012, Vol.2, No.3, 1493-1500

Cottenie, A.; Verloo, M.; Velghe, G. and Kiekens, L. (1982).Biological and analytical aspects of soil pollution.Labo of Analytical and Agro.StateUniv.Chent.Belgium.

FAO (1977).Guidelines for soil profile description. Soil Res. Devl. andGonn. Serv.Land and Water Dev. Div. Rome.

Ghoneim, A.M. (1996). Effect of submergence on some physical, chemical and biological changes of some North Delta soils as well as yield and yield components of rice plants. M.Sc. Thesis, Fac. of Agric. Kafr ElSheikh, TantaUniv.
IRRI (1987).Physical measurements in flooded rice soils: the Japanese Methodologies, International Rice Research Institute, Los Banos, Laguna.

Jackson, M.L. (1967). Soil Chemical Analysis.Prentice Hall of India, Ltd., New Delhi.

Klute, A. (1986). Methods of soil analysis (part 1). American Society of Agronomy, Inc. Soil Sci. Soc. Amer., Inc. Madison, Wisconsin, USA.Second Edition.

Lindsay, W.L. (1972). Inorganic phase equilibria in soils in Micronutrients in Agriculture. J. Mortvedt (ed.). Soil Sci. Soc. Am., Madison, Wis. pp. 48-81.

Nashy, R.M. (1995).Changes of some chemical and mineralogical soil proprieties of Al-Kanater AlKhyria Fish farming.Egypt, J. Soil Sic. 35, No. 4 pp. 465-476.

Nelson R.E. (1982): Carbonate and gypsum. In: Page A.L., Miller R.H., Keeney D.R. (eds.): Methods of soil analysis. Part 2: Chemical and microbiological properties. $2^{\text {nd }}$ ed. Am. Soc. Agron., Madison, WI: 181-198.

Okon, A.O. and Antia, O.E. (2003). Micronutrient dynamics in some wetland soils of South-Eastern Nigeria. J. Environ. Sci. China, 15(1): p. 38-42.

Page, A.L. (ed). 1982. Methods of soil analysis, part 2: chemicaland microbiological properties. Agronomy monograph No. 9 (part2). ASA/SSSA, Madison, Wisconsin.

Yongming, L.; Xianjun, J. and Peter, G. (2003).Accumulation and chemical fractionation of $\mathrm{Cu}$ in a paddy soil irrigation with $\mathrm{Cu}$ rich wastewater. Geoderma, Vol. 115, ISS. 1-2, pp. 113-120. 
تأثير إستخدام المزارع السمكية على بعض خواص التربة الكميائية وتيسر بعض العناصر الصغرى

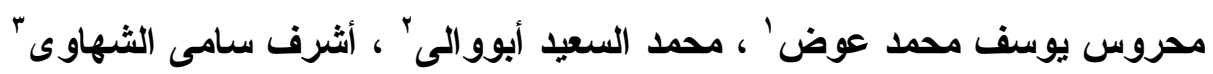

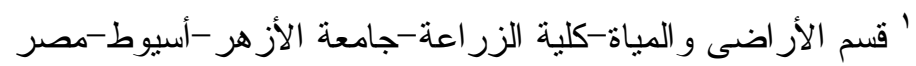

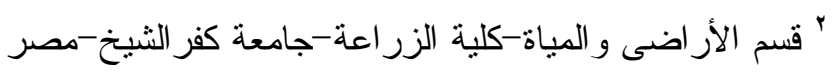

$$
\begin{aligned}
& \text { "معهد بحوث الأر اضى و المياة سمركز البحوث الزر اعية -الجيزة-مصر }
\end{aligned}
$$

الملخص:

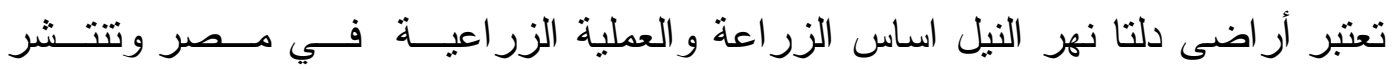

المز ارع السمكية في الجزء الشمالي لالتا النيل حيث قد تستخدم الأر اضى التى ســـق زر اعتهـــا. بالمحاصيل كز ارع سمكية لفتز ات مختلفة ولدر اسة مدى تأثير اســتخدام ار اضــى المــزارع

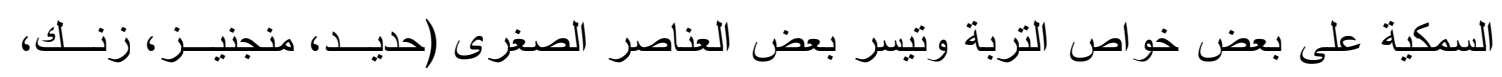
نحاس) • فقد تم حفر · ( قطاعات أرضية تمنل الاستخدامات الز اعية المختلفة فى مسساحة ... فدان بمنطقة الحامول بمحافظة كفر الثيخ بشمال الدلتا. ونشمل مز ارع سمكية و أر اضى زر اعيــة بالإضـافة الى قطاع أرضى لم تزرع من قبل (كنترول). و أشنارت النتـائج الــى زيــادة تيـسر

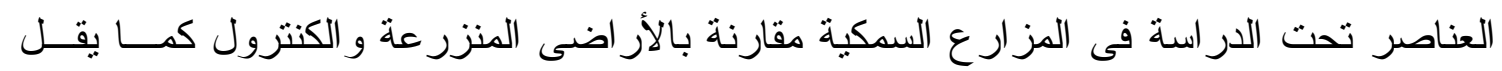

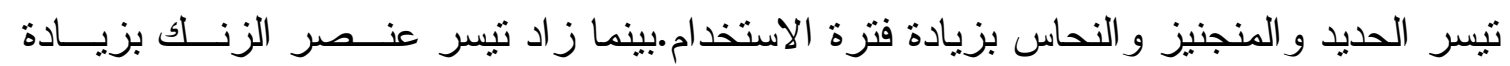
الاستخدام.يرتبط تيسر هذه العناصر معنويا بخو اص التزبةحيث وجد ارنباط معنوى موجب بـين معظم هذه العناصر ومحتوى التزبة من الاملاح و الطين و المادة العضوية وارتباط معنوى سالب بين هذه العناصر و pH التربة ومحتو اها من السلت و الرمل. 